\title{
ASSESSMENT OF QUALITY OF LIFE OF PATIENTS WITH INFLAMMATORY BOWEL DISEASE RESIDING IN SOUTHERN BRAZIL
}

\author{
Danielle COHEN ${ }^{1}$, Ceres Maltz BIN² and Ana Paula Trussardi FAYH ${ }^{2}$
}

\begin{abstract}
Context - Chronic diseases have an impact on the quality of life of the individuals. Objective - To evaluate the quality of life of adults with inflammatory bowel disease by the inflammatory bowel disease questionnaire certified for Portuguese language. Methods - We interviewed 50 individuals from both genders aged from 18 to 60 years old, with Crohn's disease and ulcerative colitis, regardless of disease activity. Results - The average age of the sample was $42.2 \pm 13.6$ years old, the disease length was 98.8 \pm 74.3 months, and $72 \%$ of patients had Crohn's disease and $14 \%$ presented disease activity. There was no significant difference in questionnaire scores of patients with different inflammatory bowel disease when they are in the remission phase (172.0 \pm 42.4 and $173.6 \pm 28.2$ for ulcerative colitis and Crohn's disease, respectively, $P=0.886$ ). When compared to scores of patients who were in crisis, it was found that they have a lower quality of life that patients in remission (123.8 \pm 44.5 and $173.3 \pm 31.5$ for patients in crisis and remission, respectively, $P=0.001)$. Conclusion - It was noticed that the quality of life of patients with inflammatory bowel disease did not differ among patients with Crohn's disease or ulcerative colitis, when patients are in remission. The main aspect which determines the loss of quality of life would be being at the stage of disease activity.
\end{abstract}

HEADINGS - Inflammatory bowel diseases. Crohn disease. Proctocolitis. Quality of life.

\section{INTRODUCTION}

The inflammatory bowel diseases (IBD), which include Crohn's disease (CD) and ulcerative colitis (UC), are chronic disorders of multifactorial causes ${ }^{(15)}$. $\mathrm{UC}$ is a condition with inflammatory response and morphological alterations restricted to the colon. The inflammation is restricted to the mucosa and is of variable severity, showing ulcerations, edema, and hemorrhage along the whole colon, while in $\mathrm{CD}$, the inflammation may involve any part of the gastrointestinal tract, from the oropharynx down to the perianal area. The inflammation is transmural, that is, the lesion trespasses the colon wall ${ }^{(11)}$.

The major symptoms are diarrhea, abdominal pain, gastrointestinal bleeding, weight loss, malnutrition and fatigue, and the diseases may have significant psychosocial implications and cause limitations in the life style of IBD patients, and consequently impact their quality of life ${ }^{(6)}$.

IBD mechanisms and treatment have not been completely elucidated yet, and the individual response of each patient to the treatment varies. Since no effective treatment has been found yet, there is a need to decrease the number of the disease's recurrences, prolong remission duration and improve quality of life $\mathrm{e}^{(13)}$.

The Crohn's disease activity index is a standard classification system that allows clinical evaluation by interpretation of the patients' symptoms. It is currently used in most clinical screenings to evaluate different effects on the symptoms of Crohn's disease activity ${ }^{(5)}$. The ulcerative colitis activity index has been proposed by several studies to help choosing the treatment and follow-up the long-term development, furthermore, it allows comparing patients in multicenter studies. The activity index of the diseases and their reach in the colon is the best way of objectively assessing which therapeutic measures will be required ${ }^{(3)}$.

However, it is necessary to define a tool tailored to evaluate aspects specific of each individual's reality, including questions about any difficulties faced in their daily routine. The questionnaire on quality of life for patients with inflammatory bowel disease (IBDQ) was proposed in 1988 in the United States by Mitchell et al. ${ }^{(14)}$ and adapted by Guyatt et al. ${ }^{(8)}$, reducing the original 150 questions to the current 32, covering four domains. The IBDQ was adapted to the Portuguese variant spoken in Brazil

Methodist University Center; ${ }^{2}$ Hospital de Clínicas de Porto Alegre, Porto Alegre, RS, Brasil.

Correspondence: Ana Paula Trussardi Fayh,RD - Rua Coronel Joaquim Pedro Salgado, 80 - Rio Branco - 90690-200 - Porto Alegre, RS, Brazil. E-mail: apfayh@yahoo.com.br. 
and to the Brazilian culture. This translated and validated version can be used to assess the quality of life of Brazilian patients with $\mathrm{IBD}^{(18)}$.

In view of these considerations, one can understand how significantly IBD may affect the daily routine of individuals with this disease. Its is crucial to assess the impact on quality of life to understand the social and psychological issues involved during the course of this disease so as to provide a more comprehensive treatment to the patients. The present study had the purpose of assessing the quality of life of patients with IBD living in the city of Porto Alegre, RS in Southern Brazil.

\section{METHODS}

\section{Sample}

Patients with IBD living in the city of Porto Alegre, aged between 18 and 60 years, were invited to take part in the study. The study was announced by electronic means and at hospitals and clinics of the city. The inclusion criterion was that all participants should have been diagnosed with $\mathrm{CD}$ or $\mathrm{UC}$ for at least 6 months, regardless of the current activity of the disease. All volunteers signed a free and informed term of consent in two counterparts, previously approved by the Research Ethics Committee of the South Methodist Educational Network, Porto Alegre (090/2008).

Additionally, for analysis of quality of life, individuals were classified according to the activity of their disease. The diseases' activity rate and its length in the colon is the best way to objectively evaluate the necessary treatment decisions $^{(3)}$, and it is based on clinical, biochemical and pharmacological criteria ${ }^{(2)}$. According to these criteria, patients are classified in disease activity or in remission when the symptoms are milder.

\section{Data collection procedures}

The volunteers filled out the questionnaire on quality of life validated for IBDQ. The Portuguese version is already a valid and reproducible tool and may be used for evaluating the quality of life of Brazilian patients with IBD ${ }^{(18)}$. Patients who declared being illiterate had the questionnaire read to them and filled out by the researcher.

The questionnaire consists of 32 questions divided into four themes: intestinal symptoms (10 questions), systemic symptoms (5 questions), emotional status (12 questions), and social functioning (5 questions). The score scale for each question ranges from 1 to 7,1 meaning that the problem is severe and 7 that the problem did not occur in the last 2 weeks.

In addition to the IBDQ questionnaire, the participants informed other data for characterizing the sample, such as weight, height, duration, and current activity status of the disease.

\section{Statistical procedures}

The data were structured and analyzed with the Statistical Package for Social Sciences version 13.0 for Windows, and the results were expressed as mean \pm S.E.M. Distribution of all continuous variables for verifying the assumption of normality (Shapiro-Wilks test) and homocedasticity of variances (Levene test) were assessed. After the study protocol had been applied, results of the IBDQ scores in the IBD types were compared through an independent $t$ test. Accepted level of significance was $P<0.05$.

\section{RESULTS}

Results point to a mature adult population, in which CD is $72 \%$ more prevalent than UC. There was a predominance of women, i.e., $62 \%$ of the total sample. Based on the nutritional classification by body mass index (BMI) (FAO/WHO, 1995), patients with $\mathrm{CD}$ were classified as eutrophic, and patients with UC were overweight. Table 1 contains data on sample description, where patients were classified by disease, but not by the disease's activity.

TABLE 1. Sample description

\begin{tabular}{lccc}
\hline & $\begin{array}{c}\text { Crohn's disease } \\
(\mathrm{n}=36)\end{array}$ & $\begin{array}{c}\text { Ulcerative colitis } \\
(\mathrm{n}=14)\end{array}$ & $\begin{array}{c}\text { Total } \\
(\mathrm{n}=50)\end{array}$ \\
\hline Age (years) & $39.75 \pm 13.33$ & $48.5 \pm 12.79$ & $42.2 \pm 13.64$ \\
Disease duration (months) & $95.41 \pm 80.83$ & $107.57 \pm 55.81$ & $98.82 \pm 74.32$ \\
Weight $(\mathrm{kg})$ & $67.66 \pm 11.57$ & $73.67 \pm 18.20$ & $69.56 \pm 14.07$ \\
Height $(\mathrm{cm})$ & $165 \pm 09$ & $166 \pm 10$ & $165 \pm 10$ \\
BMI $\left(\mathrm{kg} / \mathrm{m}^{2}\right)$ & $24.66 \pm 3.77$ & $26.95 \pm 7.82$ & $25.30 \pm 5.24$ \\
\hline
\end{tabular}

For a preliminary evaluation of the quality of life, the questionnaire's scores were added, but not separated by the disease's activity. Table 2 presents the scores on quality of life obtained in the IBDQ questionnaire and shows that there is no difference in the quality of life of patients with the different forms of the disease. Patients had a lower relative score (according to the validated questionnaire scores) in systemic and emotional symptoms, with the social symptoms having a lesser impairment to quality of life.

TABLE 2. IBDQ partial and total scores

\begin{tabular}{ccccc}
\hline & $\begin{array}{c}\text { Crohn's } \\
\text { disease } \\
(\mathrm{n}=36)\end{array}$ & $\begin{array}{c}\text { Ulcerative } \\
\text { colitis }\end{array}$ & $\begin{array}{c}\text { Total } \\
(\mathrm{n}=50)\end{array}$ & $P^{*}$ \\
\hline Intestinal & $55.72 \pm 10.35$ & $53.14 \pm 11.85$ & $55 \pm 10.73$ & 0.917 \\
Systemic & $24.38 \pm 5.33$ & $22 \pm 6.57$ & $23.72 \pm 5.73$ & 0.560 \\
Social & $29.25 \pm 6.55$ & $26.64 \pm 8.23$ & $28.52 \pm 7.07$ & 0.811 \\
Emotional & $61.69 \pm 14.28$ & $54.21 \pm 22.30$ & $59.6 \pm 17$ & 0.950 \\
\hline Total & $\begin{array}{c}170.38+ \\
33.78\end{array}$ & $156+44.97$ & $166.36+37.33$ & 0.886 \\
\hline
\end{tabular}

* $P$ value obtained by independent $t$ test

In order to evaluate the impact of the disease's activity on the quality of life of these patients, and knowing that there is no difference between the quality of life of patients with $\mathrm{CD}$ and $\mathrm{UC}$, the sample was divided by disease activity. Table 3 shows that the disease's activity significantly affects the quality of life of the patients in all symptom domains. 
TABLE 3. IBDQ scores of patients in active disease and in remission

\begin{tabular}{cccc}
\hline & $\begin{array}{c}\text { Patients in remission } \\
(\mathrm{n}=43)\end{array}$ & $\begin{array}{c}\text { Patients in active } \\
\text { disease } \\
(\mathrm{n}=7)\end{array}$ & $\boldsymbol{P}^{*}$ \\
\hline Intestinal & $56.72+9.54$ & $44.42+12.34$ & 0.004 \\
Systemic & $24.65+5.18$ & $18.00+6.05$ & 0.003 \\
Social & $29.53+6.44$ & $22.28+8.07$ & 0.01 \\
Emotional & $62.37+15.31$ & $42.57+18.05$ & 0.003 \\
Total & $173.3+31.5$ & $123.8+44.5$ & 0.001 \\
\hline
\end{tabular}

* P value obtained by independent $t$ test

It is important to compare the quality of life of our sample with data obtained by other studies reported in the literature. Table 4 shows a summary of the comparison of the scores obtained with IBDQ questionnaire in different studies in the medical literature. In this comparison, one can notice similar scores in two studies; however, they are far higher than the other study done in Amsterdam, with larger sample sizes.

TABLE 4. Comparison with other studies found in the literature

\begin{tabular}{lcccc}
\hline & $\begin{array}{c}\text { Our data } \\
(\mathbf{n}=50)\end{array}$ & $\begin{array}{c}\text { Pallis et al. }{ }^{(16)} \\
(\mathbf{n}=135)\end{array}$ & $\begin{array}{c}\text { Han et al. } .^{(10)} \\
(\mathbf{n}=30)\end{array}$ & $\begin{array}{c}\text { de Boer et al. }{ }^{(4)} \\
(\mathbf{n}=271)\end{array}$ \\
\hline Intestinal & $55+10.73$ & $58.9+10.7$ & $54.9+10.4$ & $37.3+7.7$ \\
Systemic & $23.72+5.73$ & $27.7+6.9$ & $25.3+5.9$ & $17.0+4.4$ \\
Social & $28.52+7.07$ & $29.1+7.5$ & $29.4+8.1$ & $20.0+4.7$ \\
Emotional & $59.6+17$ & $62.4+15.6$ & $64.1+13.7$ & $44.9+9.1$ \\
Total & $166.36+37.33$ & $178.1+36.9$ & $173.7+33.1$ & $119.1+22.0$ \\
\hline
\end{tabular}

\section{DISCUSSION}

The results of this study showed a mature adult sample, aged average $39.8 \pm 13.4$ years old for $\mathrm{CD}$ patients, while in patients with $\mathrm{UC}$, we found an average age higher, reaching to $48.5 \pm 12.7$ years old. Aghdassi et al. ${ }^{(1)}$, evaluating 74 patients with $\mathrm{CD}$, had an average age very close to our findings (35.7 \pm 1.4 years), as Ren et al. ${ }^{(19)}$, who found an average age of $40.9 \pm 15.3$ among the 92 patients studied. On the other hand, Pallis et al. ${ }^{(16)}$, in their study describes a sample aged 16 to 84 years old, and average age very similar to this study. These data indicate a strong concern in evaluating mature adults. The aging process coupled with chronic enhances the chances of mature adults to have losses in their quality of life. The average monthly length of $\mathrm{CD}$ and $\mathrm{UC}$ in this study was $98.2 \pm 82.4$ and $107.6 \pm 55.8$ months. Very similar results were shown by Aghdassi et al. ${ }^{(1)}$, with a 120 -month disease's length for people with DC, as well as to Pallis et al. ${ }^{(16)}$, who found a length average of 78 months for DC and 100 months for ulcerative colitis.

The nutritional condition of individuals with $\mathrm{CD}$ in this study was similar to those of patients evaluated by Aghdassi et al. ${ }^{(1)}$, which notice an average of $23.05+0,45 \mathrm{~kg} / \mathrm{m}^{2}$ of BMI from 74 Canadian patients, representing eutrophia. Importantly, the data to determine the nutritional status of individuals in this study were reported, but the literature indicates a high correlation between figures measured and reported by patients who underwent nutritional assessment ${ }^{(17)}$. Patients with IBD are more susceptible to protein-energy malnutrition caused mainly by the reduction in food intake, poor absorption, increased gastrointestinal losses and increased nutritional needs ${ }^{(9)}$. However, the fact that the vast majority of patients were in the remission of the disease may have contributed to the nutritional status assessed by anthropometric parameters is within normal limits.

Regarding the questionnaire score of quality of life, it is noticed that the issues with lower scores were related to emotional and systemic aspects. These findings coincide with those observed by Han et al. ${ }^{(10)}$ who evaluated 30 individuals in the United Kingdom; however, they differ from the ones from Pallis et al. ${ }^{(16)}$, who assessed 135 individuals in Greece. Due to the chronicity of the disease, it is justifiable that patients mention a worse quality of life regarding emotional aspects ${ }^{(16)}$, as the impact of the disease is stronger in the psychological and social aspects. Often patients are unaware of the disease itself, letting the feelings of stigma hinder your social life ${ }^{(14)}$. Guthrie et al. ${ }^{(7)}$ describe the importance of identifying and alleviating psychological distress, because they contribute to health-related quality of life loss, regardless of disease severity. Psychological factors like a depressed mood associated with anxiety and health-related quality of life, may have a negative influence on the course of $\operatorname{IBD}^{(15)}$.

Individuals with IBD are more likely to have loss in their quality of life in the period of disease activity ${ }^{(21)}$. Ren et al. ${ }^{(19)}$ in their study found a prevalence of $40.2 \%$ of patients in crisis, which scored an average of 150 points. This score exceeds the results of this study, which showed an average score of 124 points for patients with active disease. Pallis et al. ${ }^{(16)}$, found a similar average to our study, when a group with active disease was analyzed (116 points). According to Guthrie et al. ${ }^{(7)}$, psychological symptoms and severity of the disease contribute to health-related quality of life loss. According to the same author, when disease severity is taken into account and it is statistically isolated (regression analysis), there were no significant differences between $\mathrm{CD}$ and $\mathrm{UC}$ on quality of life of patients. Also in a Greek population, it is observed that the activity of the disease was the main factor on the perception of quality of life $\mathrm{e}^{(16)}$.

In an attempt to compare the results of this study to similar ones available in the literature Pallis et al. ${ }^{(16)}$ evaluating 135 individuals in Greece, and Han et al. ${ }^{(10)}$ evaluating 30 patients in the United Kingdom did not differ much in scores of the dimensions and in the total questionnaire score. However, de Boer et al. ${ }^{(4)}$ evaluating 271 individuals in Amsterdam had lower scores in all aspects and consequently in the total questionnaire score. This phenomenon can be explained due to a high prevalence $(46 \%)$ of patients presenting the disease at the time of the interview, and to the inclusion of a considerable number of patients with ileostomies, a fact which is known to decreasing quality of life of the IBDQ as an specific questionnaire to evaluate quality of life in patients with IBD, because it is widely used in literature, easy to apply and allows management through interview. 
However, this is not the only questionnaire developed to evaluate the quality of life. Depending on the questionnaire used, different classifications in quality of life can be reported in the same population. Shepanski et al. ${ }^{(20)}$ evaluated the health-related quality of life of 71 children and adolescents with IBD using the IMPACT-35 instrument, which consists of 35 questions divided into six domains (symptoms of inflammatory bowel disease, systemic symptoms, emotional functioning, social functioning, body image, treatment and interventions). On the other hand, Loonen et al..$^{(12)}$ measured the quality of life in children and adolescents with IBD using a generic instrument the TNO-AZL Children's Quality of Life questionnaitre(TACQOL), and concluded that they have impaired their quality of life, with damage in motor function and autonomy of these patients. Zahn et al. ${ }^{(22)}$ indicated a strong relation between clinical activity and endoscopic activity rates in all domains of Health-Related Quality of Life (HRQoL), questionnaire of quality of life proposed by the WHO for patients with UC.

This is the first study that evaluates the quality of life of patients with IBD residents in southern Brazil after the publication of the validation results of the questionnaire for the Portuguese language spoken in this country. Being a clinical study, it is important to note that this also has limitations. Because this sample was selected for convenience, the external validity of this study is imaired. Another aspect worth mentioning is that there is no epidemiological information of the disease in southern Brazil, so it is unknown if the analyzed sample represents the population. However, having been contributing with data on the quality of life of patients living in Brazil this study makes explicit the relevance of it and the need for further studies to supplement this information.

In this study we observed that the quality of life of patients with IBD, both with CD and with UC is not different when patients are in the remitting phase. The main aspect which determines the loss of quality of life is being at the stage of disease activity where the characteristic symptoms are exacerbated. It is important that health professionals are alert to patients' own perceptions about their health-related quality of life since this issue may reflect on the patients' care and treatment.

Cohen D, Bin CM, Fayh APT. Avaliação da qualidade de vida de pacientes com doença inflamatória intestinal residentes no sul do Brasil. Arq Gatroenterol. 2010;47(3):285-9.

RESUMO - Contexto - As doenças inflamatórias intestinais são doenças crônicas e, com isso, podem exercer impacto sobre a qualidade de vida do indivíduo. Objetivo - Avaliar a qualidade de vida de adultos com doenças inflamatórias intestinais, através do Inflammatory Bowel Disease Questionnaire validado para a língua portuguesa, e comparar esta resposta entre pacientes com a doença em atividade ou não. Métodos - Foram entrevistados 50 indivíduos de ambos os sexos, com idade entre 18 e 60 anos. Resultados - A média de idade da amostra foi de 42,2 \pm 13,6 anos, o tempo da doença foi de $98,8 \pm 74,3$ meses e $72 \%$ destes indivíduos tinham doença de Crohn. Sete indivíduos relataram estar no momento da atividade da doença, mas não houve diferença significativa entre o tempo de doença e o estado nutricional quando comparados os pacientes com atividade e em remissão da doença. Não foi verificada diferença significativa na pontuação do questionário dos pacientes com as diferentes doenças inflamatórias intestinais quando estes estão na fase remissiva ( $172 \pm 42,4$ e 173,6 $\pm 28,2$ para retocolite ulcerativa e doença de Crohn, respectivamente, $P=0,886)$. Quando comparada a pontuação dos pacientes que estavam em crise, verificou-se que esses apresentam menor qualidade de vida do que os pacientes em remissão $(123,8 \pm 44,5$ e 173,3 \pm 31,5 para os pacientes em crise e em remissão, respectivamente, $P=0,001)$. Conclusão - Foi possível verificar que a qualidade de vida dos pacientes com doenças inflamatórias intestinais não difere quando diagnosticadas nas suas duas classificações, quando os pacientes estão na remissão. $\mathrm{O}$ aspecto principal para determinação de um prejuízo na qualidade de vida seria estar na fase da atividade da doença.

DESCRITORES - Enteropatias inflamatórias. Doença de Crohn. Proctocolite. Qualidade de vida.

\section{REFERENCES}

1. Aghdassi E, Wendland BE, Stapleton M, Raman M, Allard JP. Adequacy of nutritional intake in a Canadian population of patients with Crohn's disease. J Am Diet Assoc. 2007;107:1575-80.

2. Bin C, Francesconi C, Álvares-da-Silva M. Comparação entre método funcional com avaliação subjetiva global, antropometria, inquérito alimentar e análise bioquímica na estimativa do estado nutricional de pacientes com doença de Crohn. [Dissertation]. Porto Alegre: Universidade Federal do Rio Grande do Sul - UFRGS; 2007.

3. Carter MJ, Lobo AJ, Travis SP. Guidelines for the management of inflammatory bowel disease in adults. Gut. 2004;53(Suppl):1-16.

4. de Boer AG, Wijker W, Bartelsman JF, de Haes HC. Inflammatory bowel disease questionnaire: cross-cultural adaptation and further validation. Eur J Gastroenterol Hepatol. 1995;7:1043-50.

5 Freeman HJ. Use of the Crohn's disease activity index in clinical trials of biological agents. World J Gastroenterol. 2008;14:4127-30, 2008.
6. Ghosh S, Mitchell R. Impact of inflammatory bowel disease on quality of life: results of the European Federation of Crohn's and Ulcerative Colitis Associations (EFCCA) patient survey. J Crohn's Colitis. 2007;1:10-20.

7. Guthrie E, Jackson J, Shaffer J, Thompson D, Tomenson B, Creed F. Psychological disorder and severity of inflammatory bowel disease predict health-related quality of life in ulcerative colitis and Crohn's disease. Am J Gastroenterol. 2002;97:1994-9.

8. Guyatt G, Mitchell A, Irvine EJ, Singer J, Williams N, Goodacre R, Tompkins C A new measure of health status for clinical trials in inflammatory bowel disease. Gastroenterol. 1989;96:804-10.

9. Han PD, Burke A, Baldassano RN, Rombeau JL, Lichtenstein GR. Nutrition and inflammatory bowel disease. Gastroenterol Clin North Am. 1999;28:423-43.

10. Han SW, McColl E, Steen N, Barton JR, Welfare MR. The inflammatory bowe disease questionnaire: a valid and reliable measure in ulcerative colitis patients in the northeast of England. Scand J Gastroenterol. 1998;33:961-6.

11. Hendrickson BA, Gokhale R, Cho JH. Clinical aspects and pathophysiology of inflammatory bowel disease. Clin Microbiol Rev. 2002;15:79-94. 
12. Loonen HJ, Grootenhuis MA, Last BF, Koopman HM, Derkx HH. Quality of life in pediatric inflammatory bowel disease measured by a generic and a disease specific questionnaire. Acta Paediatr. 2002;91:348-54.

13. Mikocka-Walus AA, Turnbull DA, Moulding NT, Wilson IG, Andrews JM, Holtmann GJ. Antidepressants and inflammatory bowel disease: a systematic review. Clin Pract Epidemiol Ment Health. 2006;2:24-33.

14. Mitchell A, Guyatt G, Singer J, Irvine EJ, Goodacre R, Tompkins C, Williams N, Wagner F. Quality of life in patients with inflammatory bowel disease. J Clin Gastroenterol. 1988;10:306-10.

15. Mittermaier C, Dejaco C, Waldhoer T, Oefferlbauer-Ernst A, Miehsler W, Beier M, Tillinger W, Gangl A, Moser G. Impact of depressive mood on relapse in patients with inflammatory bowel disease: a prospective 18--month follow-up study. Psychosom Med. 2004;66:79-84.

16. Pallis AG, Vlachonikolis IG, Mouzas IA. Assessing health-related quality of life in patients with inflammatory bowel disease, in Crete, Greece. BMC Gastroenterol. 2002;2:1.

17. Peixoto MR, Benício MH, Jardim PC. Validade do peso e da altura auto-referidos: o estudo de Goiânia. Rev Saúde Pública. 2006;40:1065-72.

18. Pontes RM, Miszputen SJ, Ferreira-Filho OF, Miranda C, Ferraz MB. Qualidade de vida em pacientes portadores de doença inflamatória intestinal: tradução para o português e validação do questionário "Inflammatory Bowel Disease Questionnaire". Arq Gastroenterol. 2004;41:137-43

19. Ren WH, Lai M, Chen Y, Irvine EJ, Zhou YX. Validation of the mainland Chinese version of the inflammatory bowel disease questionnaire (IBDQ) for ulcerative colitis and Crohn's disease. Inflamm Bowel Dis. 2007;13:903-10.

20. Shepanski MA, Hurd LB, Culton K, Markowitz JE, Mamula P, Baldassano RN. Health related quality of life improves in children and adolescent with inflammatory bowel disease after attending a camp sponsored by the Crohn's and Colitis Foundation of America. Inflam Bowel Dis. 2005;11:164-170.

21. Wolfe BJ, Sirois FM. Beyond standard quality of life measures: the subjective experiences of living with inflammatory bowel disease. Qual Life Res. 2008; $17: 877-86$

22. Zahn A, Hinz U, Karner M, Ehehalt R, Stremmel W. Health-related quality of life correlates with clinical and endoscopic activity indexes but not with demographic features in patients with ulcerative colitis. Inflamm Bowel Dis. 2006;12:1058-67. 